\title{
HYPNOBREASTFEEDING, STARTING EXCLUSIVE BREASTFEEDING TO BE SUCCESS
}

\author{
Ni Wayan Armini, Gusti Ayu Marhaeni
}

\begin{abstract}
Mother's Milk is the best food for infants, but often a bottleneck in exclusive breastfeeding. Various factors contributed to the failure of exclusive breastfeeding, one of which is the production of milk slightly. Hypnobreastfeeding help mothers to ensure that breastfeeding mothers can continue breastfeeding, minimal exclusively during the first six months, especially if the breast-feeding mothers must return to work.. Hypnobreastfeeding are relaxation techniques to help smooth the process of breastfeeding. The trick insert sentences positive affirmations that help breastfeeding when mothers are relaxed or very concentrated on one thing. This article aims to provide an overview of hypnobreastfeeding can provide solutions to augment milk production in breastfeeding and overcome obstacles. Expected every mother is able to provide exclusive breastfeeding to their babies without significant barriers.
\end{abstract}

Keywords: Exlusive breastfeeding, hypnobreastfeeding, affirmation, relaxation

\section{HYPNOBREASTFEEDING AWALI SUKSESNYA ASI EKSKLUSIF Ni Wayan Armini, Gusti Ayu Marhaeni}

\begin{abstract}
Abstrak: Air Susu Ibu (ASI) merupakan makanan yang terbaik bagi bayi, namun seringkali terjadi hambatan dalam pemberian ASI eksklusif. Berbagai faktor memberikan andil terhadap gagalnya pemberian ASI Eksklusif, salah satunya adalah produksi ASI yang sedikit. Hypnobreastfeeding membantu para ibu untuk memastikan agar ibu menyusui bisa terus memberikan ASI, minimal secara ekslusif selama enam bulan pertama, terutama apabila ibu menyusui tersebut harus kembali bekerja. Hypnobreastfeeding adalah teknik relaksasi untuk membantu kelancaran proses menyusui. Caranya memasukkan kalimat-kalimat afirmasi yang positif yang membantu proses menyusui di saat ibu dalam keadaan rileks atau sangat berkonsentrasi pada suatu hal. Artikel ini bertujuan untuk memberikan gambaran mengenai hypnobreastfeeding bisa memberikan solusi dalam memperbanyak produksi ASI dan mengatasi hambatan dalam menyusui. Diharapkan setiap ibu mampu memberikan ASI Eksklusif kepada bayinya tanpa hambatan yang berarti.
\end{abstract}

Kata Kunci: ASI Eksklusif, hypnobreastfeeding, afirmasi, relaksasi

\section{Pendahuluan}

Air Susu Ibu (ASI) adalah makanan yang terbaik untuk bayi hingga berusia dua tahun. Berbagai penelitian membuktikan bahwa pemberian ASI Ekslusif selama enam bulan merupakan hal yang terbaik bagi bayi. Lembaga 
Internasional UNICEF memperkirakan pemberian ASI Ekslusif sampai usia enam bulan dapat mencegah kematian 1,3 juta anak berusia di bawah lima tahun. Sayangnya, di Indonesia hanya $8 \%$ ibu memberikan ASI Ekslusif kepada bayinya sampai berumur enam bulan dan hanya $4 \%$ bayi disusui ibunya pada jam pertama kehidupannya. Padahal, sekitar 21.000 kematian bayi baru lahir di Indonesia dapat dicegah melalui pemberian ASI. ${ }^{1}$

Berbagai faktor ikut memberikan andil terhadap gagalnya ASI Eklusif. Mulai dari mitos takut kehilangan daya tarik seorang wanita, air susu basi bagi kolostrum sampai alasan bekerja, merasa ketinggalan zaman jika menyusui bayinya alias gengsi, meniru teman atau tetangga yang memberikan susu botol. Di samping itu promosi susu kaleng lebih gencar sebagai pengganti ASI serta informasi yang minim tentang ASI. $^{2,3}$

Hypnobreastfeeding membantu para ibu untuk memastikan agar ibu menyusui bisa terus memberikan ASI, minimal secara ekslusif selama enam bulan pertama, terutama apabila ibu menyusui tersebut harus kembali bekerja. Dukungan untuk menyusui di Indonesia dirasakan masih kurang, oleh karena itu para ibu menyusui harus senantiasa berusaha menciptakan kondisi yang positif bagi dirinya untuk terus bisa menyusui. ${ }^{4}$

Hypnobreastfeeding adalah teknik relaksasi untuk membantu kelancaran proses menyusui. Caranya memasukkan kalimat-kalimat afirmasi yang positif yang membantu proses menyusui di saat ibu dalam keadaan rileks atau sangat berkonsentrasi pada suatu hal. Definisi hynosis sendiri adalah suatu kondisi nirsadar yang terjadi secara alami, dimana seseorang mampu menghayati pikiran dan sugesti tertentu untuk mencapai perubahan psikologis, fisik maupun spiritual yang diinginkan. Hypnosis sendiri terjadi otomatis kapanpun seseorang dalam keadaan rileks yang dalam atau berkonsentrasi penuh. ${ }^{5,6,7}$

Dalam teknik ini, perubahan yang diinginkan adalah segala hal yang mempermudah dan memperlancar proses menyusui. Contoh kalimat sugestinya:"ASI saya keluar lancar, cukup untuk kebutuhan bayi saya,", saya merasa bahagia bisa menyusui bayi saya", saya bangga bisa memberikan yang terbaik untuk bayi saya”, saya selalu merasa tenang dan rileks di saat mulai memerah", dan sebagainya. ${ }^{8,9}$ Konsep ini berakar dari bagaimana kita 
mengendalikan pikiran, karena pikiran akan menggerakkan semuanya. Kalau niat ibu menyusui sungguh-sungguh untuk terus menyusui bayi, selalu menanamkan sugesti yang positif, serta suami dan keluarga mendukung, niscaya pemberian ASI Ekslusif enam bulan tidaklah sulit. Indonesia dan seluruh dunia membutuhkan bayi-bayi yang diberikan ASI Ekslusif untuk masa depan yang lebih cerah. ${ }^{7}$

Artikel ini bertujuan untuk memberikan gambaran mengenai hypnobreastfeeding bisa memberikan solusi dalam memperbanyak produksi ASI serta mengatasi hambatan dalam menyusui.

\section{Pembahasan}

\section{Hypnosis}

\section{A. Pengertian Hipnosis/Hipnoterapi}

Hipnosis berasal dari bahasa Yunani yang artinya tidur, tapi tidak benarbenar tidur, dimana merupakan suatu kondisi seseorang berada dalam alam bawah sadar. Seseorang yang berada dalam kondisi hipnosis, meskipun tubuhnya beristirahat (selayaknya orang tidur), masih bisa mendengar dengan jelas dan merespons informasi yang diterimanya dari luar. ${ }^{5,7,10}$

Perkembangan sejarah ilmu hipnosis dalam dunia kesehatan, sejak tahun 1890 Dr.Grantley Dick Read mengembangkan dan menerapkan ilmu hipnosis ke dalam ilmu kebidanan dengan program yang disebut "childbirth without fear". Penemuan ini kemudian dilanjutkan oleh Marie F. Mongan dengan mencetuskan program pertama yaitu Hypno-birthing dan saat ini di Indonesia, Lanny Kuswandi (seorang perawat dan bidan) sudah mulai mengembangkan dan memperkenalkan ilmu hipnostetri kepada para bidan dan dokter dengan berbagai aplikasi hipnosis yang salah satunya adalah yang akan dibahas disini tentang Hypno-breastfeeding. Hipnosis telah dipelajari secara ilmiah selama lebih dari 200 tahun sehingga dapat ditarik kesimpulan bahwa hipnosis merupakan suatu kondisi pikiran dimana fungsi analisis logis pikiran direduksi sehingga memungkinkan individu masuk ke dalam kondisi bawah sadar (sub-conscious/unconcious), dimana tersimpan beragam potensi internal yang dapat dimanfaatkan untuk lebih meningkatkan kualitas hidup. Individu yang berada pada kondisi hipnotic atau "hypnotic trance" lebih terbuka terhadap sugesti. ${ }^{7,10}$ 
Beberapa ilmuwan berpendapat bahwa hypnotherapy menstimulir otak untuk melepaskan neurotransmitter yaitu zat kimia yang terdapat di otak, encephalin dan endhorphin yang berfungsi untuk meningkatkan mood sehingga dapat merubah penerimaan individu terhadap sakit atau gejala fisik lainnya. Sementara menurut Profesor John Gruzelier, seorang pakar psikologi di Caring Cross Medical School, London, guna menginduksi otak dilakukan dengan memprovokasi otak kiri untuk non-aktif dan memberikan kesempatan kepada otak kanan untuk mengambil kontrol atas otak secara keseluruhan. ${ }^{10}$

\section{B. Pengelompokan Hypnoterapi}

Hypnoterapi dapat dikelompokkan menjadi beberapa cabang hipnosis seperti : Hypnobirthing (melahirkan tanpa rasa takut dan meminimalkan rasa sakit), Hypnobreastfeeding (bagaimana hypnosis dapat membantu melancarkan ASI), Hypnoslimming (menurunkan berat badan dengan cara menanamkan program ke bawah sadar supaya dapat mengontrol nafsu makannya), Hypnobeauty (bagaimana hipnosis dapat membantu menghaluskan kulit atau memperbesar payudara), Hypnosex (bagaimana hipnosis dapat membantu keharmonisan suami istri di atas ranjang), Hypnolearning (bagaimana hipnosis dapat membantu seorang anak agar dapat lebih optimal dalam belajar), dan masih banyak lagi manfaat hipnosis dalam kehidupan kita. ${ }^{10}$

\section{ASI Eksklusif}

\section{A. Pengertian}

ASI merupakan makanan alamiah yang paling baik bahkan terbaik bagi bayi, karena komposisi ASI selalu disesuaikan dengan apa yang dibutuhkan bayi. Selain itu, ASI juga dilengkapi dengan zat-zat pelindung DHA (decosahexaenoic acid) dan ARA (arachinoid acid) yang penting bagi pertumbuhan dan perkembangan jaringan saraf. Selain itu ASI juga mengandung lebih banyak laktosa yang penting untuk mengembangkan jaringan otak dan membantu meningkatkan pertumbuhan bakteri usus yang berguna. ASI juga mengandung jutaan sel darah putih yang beredar ke seluruh sistem pencernaan bayi dan 
merusak bakteri yang berbahaya. ASI juga mengandung immunoglobulin, yaitu protein pelawan infeksi, yang berfungsi seperti antibiotik alamiah. ${ }^{1,2}$

ASI eksklusif (exclusif breastfeeding) adalah pemberian hanya ASI saja pada 6 bulan pertama usia bayi. Pedoman internasional menganjurkan pemberian ASI eksklusif selama 6 bulan pertama berdasarkan bukti ilmiah bahwa ASI bermanfaat bagi daya tahan tubuh bayi, pertumbuhan dan perkembangannya. ASI memberikan kelengkapan semua kebutuhan bayi selama 6 bulan pertamanya. Pada usia 6 bulan, perlu diperkenalkan makanan pendamping ASI ( MPASI ) untuk memenuhi kebutuhan gizi bayi yang semakin meningkat. Bayi yang minum ASI mendapat cairan yang cukup. Komposisi ASI yang unik dan spesifik, yang tidak bisa ditandingi oleh susu formula merek apapun terdiri dari 88,1\% air, 3,3\% lemak, $0,9 \%$ protein, $7 \%$ laktosa. ${ }^{1,3}$

ASI juga mengandung zat pelindung (antibodi) yaitu Immunoglobulin, lactobacillus, bifidus, lactoferin. Kolostrum yang didapat pada awal kelahiran bayi merupakan imunisasi awalnya karena dapat melindungi bayi dari penyakit dan membersihkan lambung bayi baru lahir. ASI mudah dicerna bayi dan tidak menimbulkan alergi pada bayi. Diperkirakan $80 \%$ ibu yang melahirkan dapat memberikan ASI yang cukup bagi bayinya. Semakin sering seorang ibu menyusui semakin meningkat jumlah produksi ASI. Pemberian ASI eksklusif dapat meningkatkan bonding antara ibu dan bayinya, rahim ibu lebih cepat kembali keukuran semula dan memperjarang kehamilan. Selain itu, ASI eksklusif yang diberikan oleh ibu dalam jangka waktu lama akan membuat ibu terhindar dari kemungkinan penyakit misalnya, kanker payudara. ${ }^{1,3}$

\section{Hypnolactation / Hypnobreastfeeding}

A. Pengertian

Hypnobreastfeeding terdiri dari dua kata yaitu hypno=hipnosis yang artinya adalah suatu kondisi nirsadar yang terjadi secara alami, dimana seseorang menjadi mampu menghayati pikiran dan sugesti tertentu untuk mencapai perubahan psikologis, fisik maupun spritual yang diinginkan. untuk diketahui, pikiran bawah sadar (subconscius mind) berperan $82 \%$ terhadap fungsi diri. Sedangkan breastfeeding artinya menyusui. Jadi, proses menyusui dapat berlangsung nyaman 
karena ibu merekam pikiran bawah sadar bahwa menyusui adalah proses alamiah dan nyaman. Dasar hypno-breastfeeding adalah relaksasi yang dicapai bila jiwa raga berada dalam kondisi tenang. Adapun timbulnya suasana relaksasi dapat didukung oleh ruangan/suasana tenang, menggunakan musik untuk relaksasi, ditambah aromatherapy, panduan relaksasi otot, napas dan pikiran. ${ }^{5,6,7}$

\section{B. Keuntungan dan Manfaat Hypno-Breastfeeding}

Keuntungan dan manfaat yang dapat diperoleh dari penggunaan hipnosis dalam hypno-breastfeeding adalah ${ }^{5,6,7}$ :

1) Sebagai sarana relaksasi.

2) Biayanya relatif rendah karena tanpa penggunaan obat-obatan

3) Metode yang digunakan relatif sederhana sehingga mudah dipahami dan dipraktekan oleh orang banyak, termasuk subjek.

4) Dapat dilakukan sendiri oleh subjek (ibu menyusui) dan cukup dibantu oleh satu terapis (bidan)

5) Dapat menyehatkan unsur tindakan, perilaku, hasrat, semangat, motivasi, inisiatif, kebiasaan buruk, dan lain-lain.

6) Mempersiapkan ibu agar berhasil pada masa menyusui

7) Mempersiapkan bayi menjadi generasi yang sehat, cerdas dan kreatif

\section{Syarat Melakukan Hypnobreastfeeding 7,9,10}

1. Persiapkan secara menyeluruh tubuh, pikiran dan jiwa agar proses pemberian ASI sukses.

2. Niatkan yang tulus dari batin untuk memberi ASI eksklusif pada bayi yang kita sayangi dan yakin bahwa semua ibu, bekerja atau di rumah, memiliki kemampuan untuk menyusui/memberi ASI pada bayinya.

3. Mulailah memberi sugesti positif. Contoh kalimat sugesti atau afirmasi, misalnya "ASI saya cukup untuk bayi saya sesuai dengan kebutuhannya" atau "saya selalu merasa tenang dan rileks saat mulai memerah".Kalimat sugesti juga dapat diberikan suami. Tujuan afirmasi positif tersebut adalah untuk menjadikan aktivitas menyusui sebagai suatu kegiatan yang mudah, sederhana dan menyenangkan 
4. Siapkan suasana yang benar-benar nyaman.

5. Hypnobreastfeeding juga bisa dilakukan oleh ibu-ibu hamil untuk mempersiapkan ASI eksklusif buat sang buah hati.

\section{Tahapan Relaksasi}

Teknik hypnobreastfeeding sama dengan teknik hypnobirthing karena juga melibatkan pikiran bawah sadar dengan cara mengistirahatkan alam sadar melalui teknik relaksasi. Teknik relaksasi dalam hypnobreastfeeding terdiri atas tiga $\operatorname{tahap}^{9,10}$ :

1. Pertama; ibu melakukan relaksasi otot mulai dari puncak kepala sampai telapak kaki, termasuk wajah, bahu kiri dan kanan, kedua lengan, daerah dada, perut, pinggul, sampai kedua kaki. Caranya bisa dengan membayangkan otot-otot menjadi relaksasi.

2. Kedua; relaksasi napas. Zaman sekarang orang-orang rentan mengalami stres stres karena dituntut untuk melakukan segala sesuatu serba cepat dan terburu-buru. Apalagi, perempuan yang memiliki peran ganda sebagai seorang ibu sekaligus wanita karier. Untuk mencapai kondisi relaks adalah dengan cara tarik napas panjang melalui hidung dan hembuskan keluar pelan-pelan melalui hidung atau mulut (fokuskan pernapasan di perut). Lakukan selama beberapa kali sampai ketegangan mengendur dan berangsur hilang.

3. Ketiga; relaksasi pikiran. Seringkali pikiran seseorang berkelana jauh dari raganya. Untuk itu, belajarlah memusatkan pikiran agar berada di tempat yang sama dengan raga. Salah satu cara dengan berdiam diri atau meditasi dengan mengosongkan pikiran dan memejamkan mata dengan napas yang lambat, mendalam dan teratur selama beberapa saat. Setelah otot-otot rileks, nafas teratur, serta pikiran tenang, baru dilakukan sesi hypnobreastfeeding.

Kalau ibu-ibu menyusui ingin melakukan hypnobreastfeeding di rumah, caranya mudah, masuklah ke dalam ruangan yang tenang, nyalakan musik khusus untuk relaksasi, sediakan aroma therapy, dan ikuti panduan relaksasi otot, napas, dan pikiran yang telah dipelajari sebelumnya, baru melakukan afirmasi yang 
positif. Pikiran bawah sadar secara otomatis akan membimbing untuk melakukan atau memikirkan hal-hal tertentu, misalnya yakin bahwa kita bisa menyusui dan ASI akan mengalir deras. Cara lain yang sederhana adalah dengan mendengarkan suara bayi serta perhatikan alur napasnya. Jika hal tersebut dilakukan secara teratur, akan menimbulkan bonding dan selanjutnya memicu tubuh untuk menghasilkan hormon endorfin (hormon pembawa rasa senang dan tenang) sehingga tubuh merasa rileks. ${ }^{7}$

\section{E. Pikiran, Tubuh dan ASI}

Produksi ASI tergantung pada dua faktor yaitu faktor fisiologis dan psikologis. Kondisi stres dan kesibukan sehari-hari dapat mempengaruhi produksi ASI. Jadi pikiran bisa mempengaruhi sistem di dalam tubuh. Hypno-breastfeeding merupakan cara yang bagus untuk mendorong pola pikir dalam menyusui yang tepat. Beberapa studi penelitian menunjukkan bahwa bayi yang diberi ASI terlindungi dari sebagian besar penyakit anak-anak dan memiliki perkembangan otak lebih baik. Selain itu wanita yang menyusui memiliki resiko lebih rendah dari kanker payudara, kanker ovarium dan bahkan patah tulang panggul (akibat osteoporosis) di kemudian hari. Jadi menyusui merupakan simbiosis mutualisme antara bayi dan ibu dimana bisa saling menguntungkan. ${ }^{10}$

\section{F. Menyusui dan relaksasi}

Relaksasi yang dalam dan teratur membuat sistem endokrin, aliran darah, persyarafan dan system lain di dalam tubuh anda akan berfungsi lebih baik. Sikap positif sangatlah penting seperti merasa tenang dan rileks selama menyusui. Pada saat ibu rileks dikala menyusui maka hormone endorphin yang diproduksi ibu pun akan mengalir ke bayi Anda melalui ASI, dan ini membuat bayi anda akan merasakan kenyamanan, ketenangan yang ibu rasakan. Relaksasi hypnobreastfeeding mampu menghadirkan rasa santai, nyaman dan tenang selama menyusui dengan demikian maka seluruh system di dalam tubuh akan berjalan jauh lebih sempurna sehingga proses menyusui-pun menjadi proses yang penuh arti dan menyenangkan baik bagi ibu dan bayi. Bahkan hypnobreastfeeding mampu membantu ibu yang mengalami kesulitan saat menyusui juga dapat 
membuat ibu mampu untuk relaktasi. Dengan demikian produksi ASI cukup untuk kebutuhan bayi sampai usia 6 bulan. Kemudian bayi tetap hingga berumur dua tahun karena otak bayi mengalami perkembangan paling pesat di usia tersebut. $^{7,8,10}$

Kesimpulan dan Saran

Hypnobreastfeeding adalah cara / metode terbaru yang sangat baik untuk membangun niat positif dan motivasi dalam menyusui serta mampu memaksimalkan kuantitas dan kualitas ASI. Berbagai cara dilakukan ibu menyusui, mulai dari konsumsi sayuran hingga jamu tertentu agar dapat memenuhi kebutuhan ASI sang buah hati. Kini teknik terbaru hypobreastfeeding diyakini dapat membantu hal tersebut. Keuntungan dan manfaat yang dapat diperoleh dari penggunaan hipnosis dalam hypno-breastfeeding adalah Sebagai sarana relaksasi, Biayanya relatif rendah karena tanpa penggunaan obat-obatan, Metode yang digunakan relatif sederhana sehingga mudah dipahami dan dipraktekkan oleh ibu serta dapat dilakukan sendiri oleh ibu menyusui dan cukup dibantu oleh satu terapis bidan. Dengan melakukan hypnobreastfeeding, para ibu menyusui dapat memproduksi SI yang berlimpah yang dapat memnuhi kebutuhan bayi sehingg ibu berhasil pada masa menyusui, dan mempersiapkan bayi menjadi generasi yang sehat, cerdas dan kreatif.

Daftar Pustaka

1. Roesli, U., 2009, Mengenal ASI Eksklusif, Jakarta: Trubus Agriwidya

2. Suradi., 2003, Tidak Etisnya Promosi Susu Formula, Jakarta: Warta Konsumen, No. 4 Tahun XXV.

3. Aidam BA, Perez-Escamilla R, Lartey A, Aidam J, 2005, Factors associated with exclusive breastfeeding in Accra, Ghana. European Journal of Clinical Nutrition. [ diunduh $17 \mathrm{Mei}$ 2011] 59, 789-796. Tersedia dari www.nature.com/ejen 
4. Andriana,Evariny. Melahirkan tanpa Rasa Sakit Dengan Metode Relaksasi

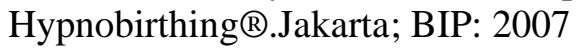

5. Astin JA, Shapiro SL, Eisenberg DM, Forys KL. Mind-Body Medicine: State Of The Science, Implications For Practice. J Am Board Fam Pract. 2003; 16(2): 131-37

6. Aprillia, Y, 2014 Hypnobreastfeeding, Solusi Cerdas Meningkatkan Produksi ASI

http://www.bidankita.com/hypnobreastfeeding-solusi-cerdas-meningkatkanproduksi-asi/

7. Kuswandi L, Aprilia Y. Basic hypnosis \& hypno-birthing. Dalam Basic hypnosis \& hypno-birthing workbook; 6-8 Mar 2009; Bali, Indonesia; Pro V Clinic (Holistic Health Care); 2009. h. 7-55.

8. Ayahbunda. 2015. Lancar ASI dengan Hypnobreastfeeding, [diunduh 30 Januari 2016]. Tersedia di: http://www.ayahbunda.co.id/kehamilanpsikologi/lancar-asi-dengan-hypnobreastfeeding

9. Nurindra Y. Hypnotherapy Fundamental: A Journey To The Sub-Conscious World. Dalam Hypnothrepy Fundamental workshop; 6-7 Maret 2010; Bandung, Indonesia; Yan Nurindra School of Hypnotism; 2010. h. 1-31.

10. James T, Flores L, Schober J. Hypnosis: a comprehensive guide producing deeptrance phenomena. UK: Cromwel Press; 2000. h. 1-9. 